\title{
TINGKAT KEPUASAN PASIEN TERHADAP PELAYANAN INFORMASI OBAT (PIO) DI PUSKESMAS KANDANG KOTA BENGKULU
}

\author{
Esti Sorena ${ }^{1}$, Samwilson Slamet ${ }^{1}$, Misse Margaret ${ }^{2}$ \\ (1)Prodi D3 Keperawatan FMIPA Universitas Bengkulu \\ (2)Prodi D3 Farmasi FMIPA Universitas Bengkulu \\ esorena@unib.ac.id
}

\begin{abstract}
Abstrak
Pelayanan Informasi Obat (PIO) wajib diberikan oleh tenaga farmasi yang berkaitan dengan penggunaan obat yang diserahkan kepada pasien dan penggunaan obat secara tepat, aman dan rasional atas permintaan masyarakat. Pemberian informasi obat memiliki peranan penting dalam rangka memperbaiki kualitas hidup pasien dan menyediakan pelayanan bermutu dapat menurun akibat adanya ketidakpatuhan terhadap program pengobatan. Penelitian ini bertujuan untuk mengetahui tingkat kepuasan pasien terhadap pelayanan informasi obat di Puskesmas Kandang. Metode penelitian ini berupa deskriptif. Populasi pada penelitian ini berjumlah 720 orang. Sampel pada penelitian ini sebanyak 88 orang responden yaitu pasien yang menebus obat di depo farmasi Puskesmas Kandang. Teknik pengambilan sampel dalam penelitian ini menggunakan teknik purposive sampling. Pengumpulan data dilakukan melalui kuesioner yang dibagikan secara langsung kepada 88 responden. Analisis data diukur menggunakan skala likert. Hasil penelitian tingkat kepuasan pasien terhadap pelayanan informasi obat di Puskesmas Kandang didapatkan hasil puas (76\%) terhadap pelayanan informasi obat yang diberikan oleh petugas farmasi di Puskesmas Kandang Kota Bengkulu.
\end{abstract}

Kata Kunci : Kepuasan Pasien, Pelayanan Informasi Obat, Pelayanan Kefarmasian

\begin{abstract}
Drug Information Services must be provided by pharmacists relating to the use of drugs submitted to patients and the use of drugs appropriately, safely and rationally at the request of the community. Providing drug information has an important role to play in improving the quality of life of patients and providing quality services can decrease due to non-compliance with treatment programs. This study aims to determine the level of patient satisfaction with drug information services at home health centers. This research method is descriptive. The population in this study amounted to 720 people. The samples in this study were 88 respondents, namely patients who redeemed drugs at the pharmacy depot Puskesmas Kandang. The sampling technique in this study used purposive sampling technique. Data collection was carried out through a questionnaire that was distributed directly to 88 respondents. Data analys was measured using a Likert scale. The results of the study of the level of patient satisfaction with drug information services at the health center, obtained results satisfied with the service of drug information provided by pharmacists at the health center Bengkulu City..
\end{abstract}

Keyword : Patient Satisfaction, Drug Information Services, Pharmaceutical Servis 


\section{LATAR BELAKANG}

Pelayanan kefarmasian telah bergeser dari drug oriented menjadi patien oriented dengan filosofi pelayanan kefarmasian (pharmaceutical care). Pharmaceutical care salah satunya pelayanan mengenai informasi obat, khususnya obat dengan resep yang ditulis dokter. Diharapkan pasien akan dapat memberikan penilaian tersendiri terhadap pelayanan yang diberikan oleh tenaga farmasi. Pasien yang merasa puas dengan jasa pelayanan yang diterimanya akan memperlihatkan kecendrungan yang besar untuk menggunakan kembali jasa yang ditawarkan oleh pemberi jasa tersebut (Prabandari, 2017).

Apoteker dan tenaga teknis kefarmasian dituntut untuk meningkatkan pengetahuan, keterampilan dan perilaku agar dapat berinteraksi langsung dengan pasien. Pelayanan yang semula hanya fokus pada pengelolaan sebagai komuditi menjadi pelayanan komprehensif, bukan hanya pengelolaan obat namun mencakup pelayanan pemberian informasi pengunaan obat yang rasional, monitoring penggunaan obat untuk mengetahui kemungkinan terjadinya kesalahan pengobatan (medication eror) dan pengobatan berbasis pasien dengan tujuan meningkatkan kualitas hidup pasien (PP No.51, 2009).

Pelayanan Informasi Obat (PIO) wajib diberikan oleh tenaga farmasi yang berkaitan dengan penggunaan obat yang diserahkan kepada pasien dan penggunaan obat secara tepat, aman dan rasional atas permintaan masyarakat. Pemberian informasi obat memiliki peranan penting dalam rangka memperbaiki kualitas hidup pasien dan menyediakan pelayanan bermutu dapat menurun akibat adanya ketidakpatuhan terhadap program pengobatan. Penyebab ketidakpatuhan tersebut salah satunya disebabkan kurangnya informasi tentang obat, Selain masalah kepatuhan pasien juga mengalami efek yang tidak diinginkan dari penggunaan obat. Dengan diberikan informasi obat kepada pasien maka masalah terkait obat seperti penggunaan obat tanpa indikasi, dosis obat terlalu tinggi, dosis subterapi, serta interaksi obat dapat dihindari (Adityawati Dkk, 2016).

Ketidakpatuhan (Non Compliance) dan ketidaksepahaman (Non Corcondance) pasien dalam menjalani terapi salah satu penyebab kegagalan terapi. Hal ini sering disebabkan karena kurangnya pengetahuan dan pemahaman pasien tentang obat dan segala sesuatu yang berhubungan dengan penggunaan obat untuk terapinya. Oleh karena itu untuk mencegah penggunaan obat yang salah (drug misuse) dan untuk menciptakan pengetahuan dan pemahaman pasien dalam penggunaan obat yang akan berdampak pada kepatuhan pengobatan dan keberhasilan terapi maka sangat diperlukan pelayanan informasi obat untuk pasien dan keluarga melalui konseling obat (Direktorat Bina Farmasi dan klinik, 2007).

Kepuasan pasien adalah suatu tingkat perasaan pasien yang timbul sebagai akibat dari kinerja layanan kesehatan yang diperoleh setelah pasien membandingkan dengan apa yang dirasakan (Pohan, 2006).

Dasar pertimbangan kepuasan pasien salah satunya kesesuaian antara biaya yang dikeluarkan pasien terhadap barang dan jasa yang diperolehnya 
menunjukan bahwa pasien sering tidak puas dengan jumlah informasi yang mereka terima dari tenaga kesehatan (Lidya, 2010).

Kepuasan merupakan pengukuran secara luas kegiatan tentang tingkat kepuasan masyarakat yang diperoleh dari hasil pengukuran atas pendapat masyarakat dalam memperoleh pelayanan dari penyelenggaraan pelayanan publik. Mengingat Jenis publik sangat beragam dengan sifat dan karateristik yang berbeda, maka survei kepuasan masyarakat dapat menggunakan metode dan teknik survei yang sesuai (Departemen Kesehatan, 2014).

Puskesmas Kandang Mas terletak di jalan RE. Martadinata, Kecamatan Kampung Melayu. Wilayah kerja puskesmas kandang terdiri dari 3 kelurahan antara lain kelurahan kandang, kelurahan kandang mas, kelurahan muara dua. Pada survei pendahuluan dan dari data rekapan resep diketahui bahwa setiap bulan resep yang dilayani apotek puskesmas kandang kota Bengkulu yaitu 720 resep perbulan. Jumlah kunjungan pasien pada puskesmas kandang perhari lebih kurang 30 pasien. Dengan demikian jumlah resep yang dilayani oleh 2 Tenaga Teknis Kefarmasian (TTK) perhari 30 resep. Sehingga pasien dalam jumlah besar tiba di apotek secara bersamaan mengakibatkan proses pengerjaan resep berjalan lambat dan juga dalam pelayanan informasi obat jarang dilakukan kepada pasien karena beberapa faktor diantaranya kurangnya tenaga kefarmasian dipuskesmas tersebut dengan kunjungan pasien yang cukup banyak. Oleh karena itu, pada penelitian ini peneliti merasa tertarik ingin mengetahui seberapa puas pasien terhadap pelayanan informasi obat di Puskesmas Kandang Kota Bengkulu.

\section{METODE}

Jenis penelitian yang digunakan adalah penelitian deskriptif yang menggambarkan tingkat kepuasan pasien terhadap pelayanan informasi obat di Puskesmas Kandang Kota Bengkulu, yang bertujuan untuk mengetahui tingkat kepuasan pasien terhadap Pelayanan Informasi obat di Puskesmas Kandang. Populasi dalam penelitian ini adalah semua pasien yang menebus resep di depo farmasi Puskesmas Kandang Kecamatan Kampung Melayu Kota Bengkulu. menggunakan metode Purposive Sampling dimana metode ini meggunakan kriteria yang telah dipilih oleh peneliti dalam memilih sample sebanyak 88 sample.

Lokasi penelitian ini di lakukan di Puskesmas Kandang Kecamatan Kampung Melayu Kota Bengkulu. Penelitian ini menggunakan kuisioner dimana dilakukan dengan menggunakan alat atau instrumen penelitian berupa angket dengan memberikan daftar pertanyaan kepada respoden dengan harapan responden memberikan respon atas pertanyaan yang diberikan oleh peneliti. Kuesioner ini di lakukan validasi dan reabilitas 0,05 .

Penelitian ini menggunakan analisa data secara kuantitatif berdasarkan skala likert.

\section{Hasil}

Pada penelitian ini dilakukan di puskesmas kandang kecamatan kampung melayu yang terletak di jalan RE Martadinata kunjungan 
pasien yang berobat di puskesmas kandang dalam waktu sebulan sebanyak 720 pasien, dengan sampel yang diambil berdasarkan perhitungan slovin didapatkan 88 responden. Responden penelitian ini adalah pasien yang menebus obat di Depo Farmasi Puskesmas Kandang Mas Kota Bengkulu. Maka diperoleh hasil penelitian tentang Tingkat Kepuasan Pasien Terhadap Pelayanan Informasi Obat Tahun 2020

\section{A. Karateristik Responden}

Tabel 1. Data Karakter Responden

\begin{tabular}{lll}
\hline VARIABEL & JML & $\%$ \\
\hline
\end{tabular}

Jenis Kelamin

- Laki-laki $34 \quad 38.64 \%$

\begin{tabular}{lll} 
- Perempuan & 54 & $61.36 \%$ \\
\hline Jumlah & 88 & $100 \%$
\end{tabular}

Umur

- 15-25 Tahun 21

$23.86 \%$

- 26-30 Tahun 9

$10.23 \%$

- 31-40 Tahun 18

$20.45 \%$

- 41-50 Tahun 15

$17.04 \%$

- 51-60 Tahun 8

- >60 Tahun

\begin{tabular}{lll}
\hline Jumlah & 88 & $100 \%$ \\
\hline
\end{tabular}

Pendidikan

- SD 17

$19.32 \%$

- SMP

8

$9.1 \%$

- SMA

20

$22.73 \%$

- Diploma/Sarj

$43 \quad 48.86 \%$
ana

\begin{tabular}{lll}
\hline Jumlah & 88 & $100 \%$ \\
\hline
\end{tabular}

Berdasarkan tabel 1, diketahui bahwa responden penelitian sebagian besar adalah perempuan berjumlah 54 orang (61.36\%). Mayoritas responden berusia $15-25$ th sebanyak 21 orang $(23.86 \%)$. Dan mayoritas responden berpendidikan diploma atau sarjana sebanyak berpendidikan 43 orang (48.86\%).

B. Persepsi Pasien terhadap Pelayanan Informasi Obat di Puskesmas Kandang

1. Petugas memberi informasi tentang nama obat

\section{petugas memberi informasi tentang nama obat}

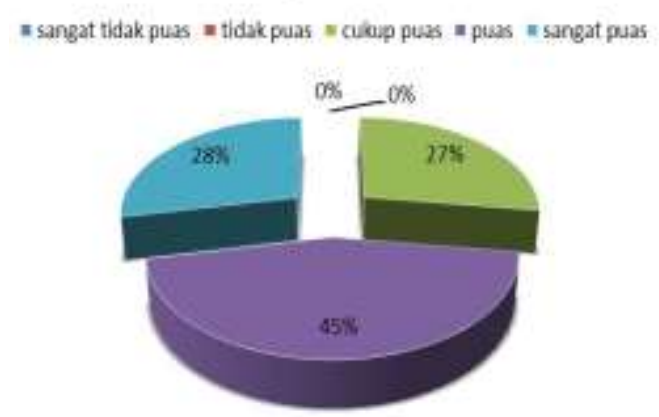

2. Petugas memberi informasi tentang dosis obat

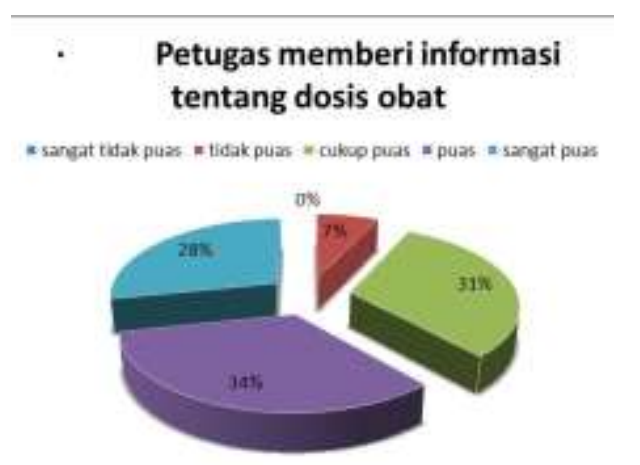


3. Petugas memberi informasi tentang cara pemakaian obat

\section{Petugas memberi informasi} tentang cara pemakaian obat

* sangat tidak puas = tidak puas = cukup puas " puas " sangat puas

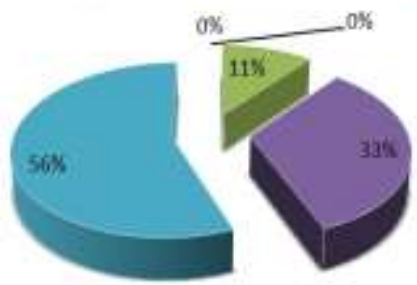

4. Petugas memberi informasi tentang cara penyimpanan obat

Petugas memberi informasi tentang cara penyimpanan obat

Esangat tidak puas = tidak puas an cukup puas = puas = sangat puas

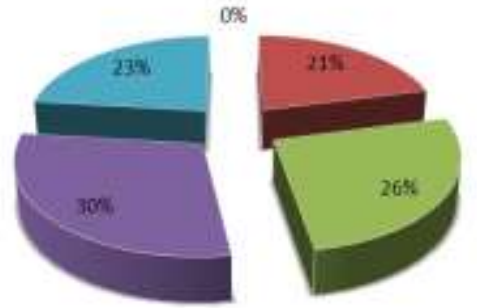

5. informasi tentang tindakan yang harus dilakukan terhadap obat yang tersisa

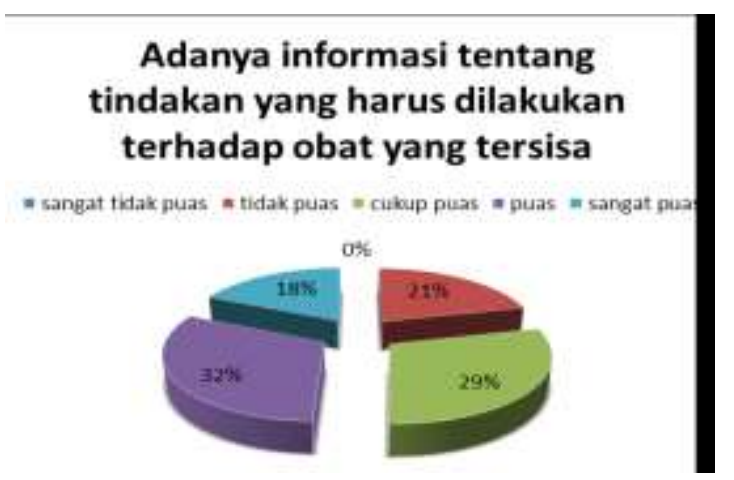

6. Petugas

menyampaikan tentang efek samping yang timbul setelah minum

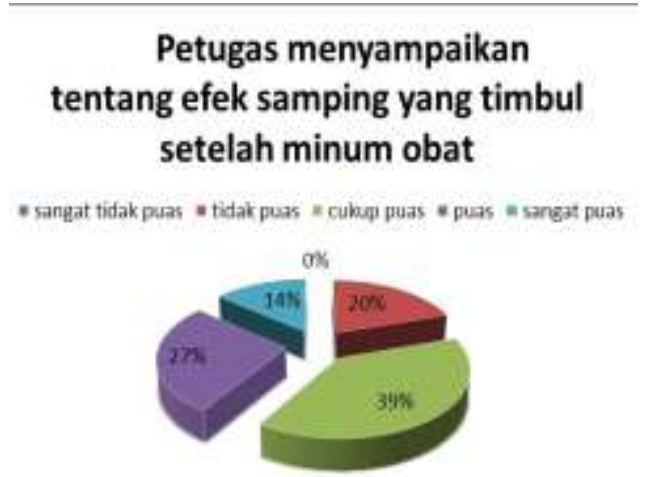

7. Pelayanan informasi obat menggunakan bahasa yang dimengerti pasien

\section{Pelayanan informasi obat menggunakan bahasa yang dimengerti pasien}

m sangat tidak puas $=$ tidak puas $=$ cukup puas $=$ puas $=$ sangat puas

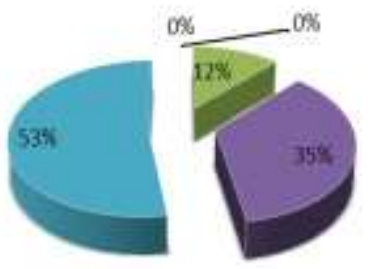

8. Petugas menjawab dengan cepat dan tanggap saat melayani pasien

Petugas menjawab dengan cepat dan tanggap saat melayani pasien

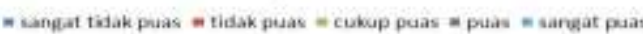

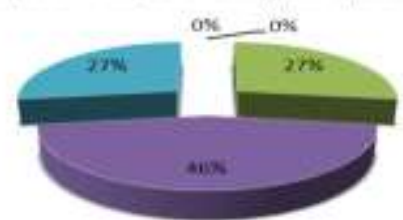


9. Informasi obat diberikan tanpa pasien harus meminta

\section{Setiap keluhan pasien diatasi dengan cepat}

E sangat tidak puas $\mathbf{m}$ tidak puas $\mid$ cukup puas m

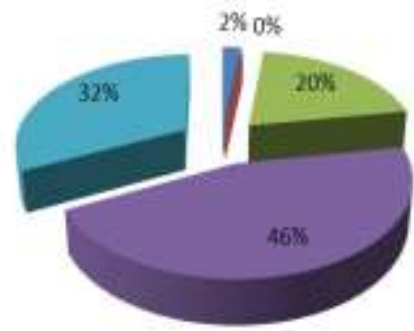

10. Petugas memberi informasi obat secara tertulis bila pasien kurang paham

\section{Petugas memiliki pengetahuan serta kemampuan yang mencukupi dalam memberikan informasi obat}

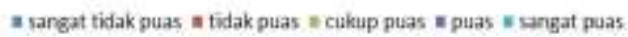

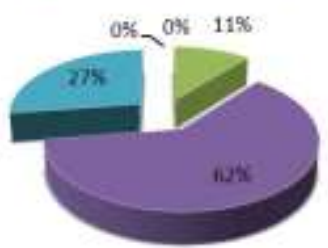

11. Petugas bersikap ramah dan sopan dalam memberikan informasi obat

Informasi obat diberikan tanpa pasien harus meminta

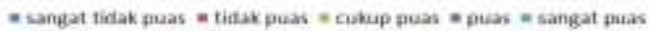

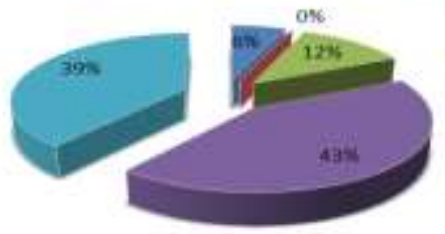

12. Petugas memberikan perhatian yang sama kepada semua pasien

\section{Petugas memberi informasi obat secara tertulis bila pasien kurang paham \\ " sangat tidak puas $=$ tidak puas = cukup puas $=$ puas " sangat puas

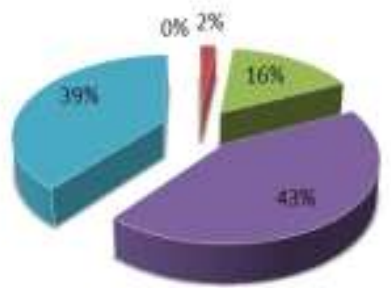

13. Tersedianya informasi obat dalam bentuk brosur

Petugas bersikap ramah dan sopan dalam memberikan informasi obat

m sangat fidak puas $\mathbf{m}$ tidak puas a cukup puas $\mathbf{m}$ puas $\mathbf{m}$ sangat puas

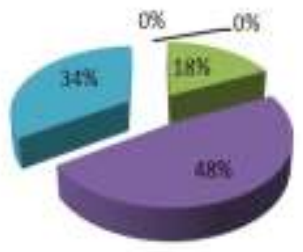

\section{DISKUSI}

Dari tabel 2 tentang karateristik responden dapat ditarik kesimpulan sebagian besar responden berjenis kelamin perempuan sebanyak 54 orang berumur 15-25 tahun sebanyak 21 orang dengan berpendidikan diploma/sarjana sebanyak 43 orang.

Diagram 1. tingkat kepuasan responden pada informasi yang diberikan petugas memberi informasi 
tentang nama obat memiliki persepsi jawaban puas 44\%. Diketahui bahwa sebagian responden merasa puas terhadap pelayanan yang diberikan petugas farmasi dalam memberikan informasi mengenai nama obat. Sehingga pasien merasa pelayanan yang diberikan sudah sesuai dengan harapan pasien yang mendapatkan pelayanan.

Dari diagram 2 hasil jawaban tingkat kepuasan responden pada informasi yang diberikan petugas memberi informasi tentang dosis obat memiliki persepsi jawaban puas 33\%, sedangkan sangat puas $28 \%$, dapat diketahui bahwa sebagian besar pasien responden merasa puas terhadap pelayanan tersebut. Meskipun ada beberapa pasien yang merasa tidak puas terhadap pelayanan informasi obat mengenai dosis, hal itu disebabkan karena minimnya penjelasan terkait informasi obat yang diberikan

Dari diagram 3 tingkat kepuasan responden pada informasi yang diberikan petugas memberi informasi tentang cara pemakaian obat memiliki persepsi jawaban, puas 33\%, sedangkan sangat puas $56 \%$, hasil dari data diatas menunjukkan bahwa pasien merasa sangat puas terhadap pelayanan yang diberikan petugas farmasi. Sehingga pasien merasa pelayanan yang diberikan sudah sesuai harapan pasien yang mendapatkan pelayanan tersebut.

Dari diagram 4 tingkat kepuasan responden pada informasi yang diberikan petugas memberi informasi tentang cara penyimpanan obat memiliki persepsi jawaban puas 29\%, sedangkan sangat puas $23 \%$, hasil dari data diatas menunjukkan sebagian pasien merasa puas terhadap pelayanan yang diberikan petugas farmasi. meskipun ada beberapa orang yang menjawab tidak puas.

Dapat dilihat pada diagram 5 tingkat kepuasan responden pada informasi yang diberikan petugas adanya informasi tentang tindakan yang harus dilakukan terhadap obat yang tersisa memiliki persepsi jawaban cukup puas $29 \%$, puas $31 \%$, sedangkan sangat puas $18 \%$, Dari data tersebut menunjukkan bahwa sebagian besar responden merasa puas terhadap pelayanan yang diberikan kepada petugas farmasi. Meskipun ada beberapa responden yang merasa tidak puas, hal itu disebabkan karena adanya pasien 
yang tidak mendapatkan penjelasan mengenai obat yang tersisa.

Dilihat pada diagram 6 tingkat kepuasan responden pada informasi yang diberikan petugas menyampaikan tentang efek samping yang timbul setelah minum obat memiliki persepsi jawaban cukup puas $39 \%$, puas $27 \%$, sedangkan sangat puas $14 \%$, Pada diagram 7 tingkat kepuasan responden pada informasi yang diberikan petugas memberi Pelayanan informasi obat menggunakan bahasa yang dimengerti pasien memiliki persepsi puas 35\%, sedangkan sangat puas $52 \%$, dari data diatas menunjukkan bahwa sebagian responden merasa sangat puas terhadap pelayanan tersebut.

Pada diagram 8 tingkat kepuasan responden pada informasi yang diberikan Petugas menjawab dengan cepat dan tanggap saat melayani pasien memiliki persepsi jawaban puas $45 \%$, dari data diatas menunjukan bahwa sebagian responden merasa puas terhadap pelayanan tersebut. Hal ini dapat terjadi karna keinginan petugas farmasi memberikan kecepatan dalam pelayanan farmasi.
Diagram 9 tingkat kepuasan responden pada informasi yang diberikan Petugas menjawab Setiap keluhan pasien diatasi dengan cepat memiliki persepsi jawaban sangat tidak puas $2 \%$, tidak puas $0 \%$, cukup puas $20 \%$, puas $45 \%$, sedangkan sangat puas $32 \%$ Hal ini menunjukan persepsi jawaban tertinggi berdasarkan pertanyaan mengenai Petugas menjawab Setiap keluhan pasien diatasi dengan cepat adalah puas $(45$

Pada diagram 10 tingkat kepuasan responden pada informasi yang diberikan Petugas memiliki pengetahuan serta kemampuan yang mencukupi dalam memberikan informasi obat memiliki persepsi jawaban sangat tidak puas dan tidak puas $0 \%$, cukup puas $11 \%$, puas $61 \%$, sedangkan sangat puas 27\%. Dari data diatas menunjukkan bahwa tenaga farmasi memiliki pengetahuan dan kemampuan dalam memberi informasi obat kepada pasien.

Diagram 11 tingkat kepuasan responden pada informasi yang diberikan Petugas memberi informasi obat diberikan tanpa pasien harus meminta memiliki persepsi jawaban sangat tidak puas $6 \%$, tidak puas $0 \%$, 
cukup puas $12 \%$, puas $43 \%$, sedangkan sangat puas 39 ada beberapa pasien yang menjawab sangat tidak puas, hal ini dikarenakan petugas tidak memberikan penjelasan tentang obat kecuali pasien yang meminta. Terkadang obat diserahkan begitu saja kepada pasien. Hal ini dikarenakan banyaknya pasien yang mengantri membuat petugas hanya memberikan informasi obat untuk obat yang memang memerlukan informasi khususnya saja.

Dari diagram 12 tingkat kepuasan responden pada informasi yang diberikan Petugas memberi informasi obat secara tertulis bila pasien kurang begitu paham persepsi jawaban sangat tidak puas $0 \%$, tidak puas $2 \%$, cukup puas $16 \%$, puas $43 \%$, sedangkan sangat puas $39 \%$, dari data diatas menunjukkan bahwa tenaga farmasi selalu memberi informasi obat secara tertulis jika pasien tidak atau kurang paham terhadap informasi obat yang dijelaskan.

Dilihat pada diagram 13 tingkat kepuasan responden pada informasi yang diberikan Petugas bersikap ramah dan sopan santun dalam memberikan informasi obat persepsi jawaban sangat tidak puas dan tidak puas $0 \%$, cukup puas $18 \%$, puas $48 \%$, sedangkan sangat puas 34\% Hal ini menunjukan persepsi jawaban tertinggi berdasarkan pertanyaan mengenai Petugas bersikap ramah dan sopan santun dalam memberikan informasi obat adalah puas dengan persentase sebanyak $48 \%$. Dari data diatas menunjukkan bahwa tenaga farmasi selalu bersikap ramah terhadap semua pasiennya.

Dari diagram 14 tingkat kepuasan responden pada informasi yang diberikan Petugas memberikan perhatian yang sama kepada semua pasien persepsi jawaban sangat tidak puas dan tidak puas $0 \%$, cukup puas $8 \%$, puas $52 \%$, sedangkan sangat puas $40 \%$ Hal ini menunjukan persepsi jawaban tertinggi berdasarkan pertanyaan mengenai Petugas memberikan perhatian yang sama kepada semua pasien adalah puas dengan persentase sebanyak 52\%. dari data diatas menunjukkan bahwa petugas farmasi tidak memandang status sosial pasien dalam memberikan pelayanan.

Dapat dilihat pada diagram 15 tingkat kepuasan responden pada fasilitas Puskesmas yaitu tersedianya informasi obat dalam bentuk brosur 
persepsi jawaban sangat tidak puas $16 \%$, tidak puas $12 \%$, cukup puas $19 \%$, puas $40 \%$, sedangkan sangat puas $12 \%$ Hal ini menunjukan persepsi jawaban tertinggi berdasarkan pertanyaan tersedianya informasi obat dalam bentuk brosur adalah puas dengan persentase sebanyak $40 \%$. dari data diatas menunjukkan bahwa responden puas terhadap ketersediaan brosur sebagai informasi obat.

\section{KESIMPULAN}

Berdasarkan hasil penelitian yang diperoleh dapat disimpulkan bahwa tingkat kepuasan pasien terhadap pelayanan informasi obat di Puskesmas Kandang Kota Bengkulu termasuk dalam kategori puas, Kepuasan pasien adalah suatu tingkat perasaan pasien yang timbul sebagai akibat dari kinerja layanan kesehatan yang diperolehnya setelah pasien membandingkan dengan apa yang diharapkanya. Berdasarkan hasil penelitian yang diperoleh dapat disimpulkan bahwa tingkat kepuasan pasien terhadap pelayanan kefarmasian di Puskesmas Kandang Kota Bengkulu adalah puas.

\section{DAFTAR PUSTAKA}

Adityawati, Dkk. 2016. Evaluasi

Pelayanan Informasi Obat Pada

Pasien Rawat Jalan di Instansi

Farmasi Puskesmas Garbag I.

Magelang Universitas

Muhammadiyah Magelang.

Arikunto, S. 2017. Prosedur Penelitian. Rineka Cipta.

Aspuah, S. 2013. Kumpulan Kuesioner Instrumen Penelitian Kesehatan. Yogyakarta: Medical Book

Direktorat Bina Farmasi Komunitas dan Klinik. 2007. Pedoman Konseling Pelayanan Kefarmasian di Sarana Kesehatan. Jakarta.

Ginting, A. 2009. Penerapan Standar Pelayanan Kefarmasian di Apotek kota Medan. Medan. Skripsi. Universitas Sumatra Utara.

Husni, Dkk. 2018. Gambaran Tingkat Kepuasan Pasien Terhadap Pelayanan Informasi Obat di Puskesmas Karang Intan 2 Kecamatan Karang Intan Kabupaten Banjar. Kalimantan Selatan. Sekolah Tinggi Ilmu Kesehatan Borneo.

Riadi Mukhlisin. Kepuasan Pasien. https://www.dosenpendidikan.c o.id/kepuasanpasien/27/01/2020.

Kotler P dan Keller K.L. 2016. Marketing Managemen 15. Perason Education, Inc. 
Lidya P Manurug. 2010. Analisis Tingkat Kepuasan Pasien Rawat Jalan Terhadap Pelayanan Instalansi.

Mawaliya Wifda. 2011. Analisis Tingkat Kepuasan Pasien Rawat Jalan Terhadap Kualitas Terhadap Pelayanan Informasi Obat di Instalasi Rumah Sakit Ortopedi Surakarta Periode Maret-Mei 2011. Surakata. Universitas Muhammadiyah Surakarta.

Nooria W. 2008. Pengaruh Persepsi Kualitas Jasa Pelayanan Terhadap Kepuasan dan Loyalitas Pelanggan di RSU Saras Husada Purworejo. Skripsi. Fakultas Psikologis. Surakarta. Universitas Muhammadiyah Surakarta.

Nursalam. 2011. Manajemen

Keperawatan edisi 3. Jakarta:

Salemba Medika.

Peraturan Kementrian Kesehatan Republik Indonesia Tahun 2016 Tentang Standar Pelayanan Minimal untuk Kepuasan Pasien.

Peraturan Mentri Kesehatan No. 74

Tahun 2016 Tentang Standar Pelayanan Kefarmasian di Puskesmas

Peraturan Pemerintah No. 51 Tahun 2009 Tentang Pekerjaan Kefarmasian.

Pohan. 2013. Jaminan Mutu Layanan Kesehatan Dasar-Dasar Pengertian dan Penerapan. Jakarta. 